\title{
Pakistan: A Case of Premature Deindustrialization?
}

\section{Naved Hamid* and Maha Khan ${ }^{* *}$}

\begin{abstract}
While "deindustrialization" is now considered normal for developed countries, recent trends show that many developing countries have seen their share of manufacturing employment peak at far earlier levels of income than in advanced countries. This new occurrence, which blocks off the main avenue for a country to catch up with more advanced economies, has been called "premature deindustrialization." As a result of stagnation in manufacturing since 2007, Pakistan is on the brink - if not already in the process - of premature deindustrialization. This paper focuses on (i) growth trends in manufacturing and the economy, (ii) developments in the context of premature deindustrialization in Pakistan, and (iii) the change in the country's structure of industry.

We adapt and apply the industrial sophistication index developed by Lall, Weiss, and Zhang (2005) to the Pakistan Standard Industrial Classifications in the Census of Manufacturing Industries. The structure of industry in Pakistan, Sindh, and Punjab is mapped from 1990-99 to 2005/06 (2010/11 for Punjab) on the basis of a sophistication index score. Our analysis substantiates the conclusion that Pakistan's industrial structure has stagnated, drawing on analyses of export data in other studies. It also indicates that our finding of modest upgrading in the industry sector on the basis of an intuitive division of industries into low-technology and high-technology industries may have been too optimistic. Revitalizing manufacturing growth will require Pakistan to once again adopt a proactive industrial policy to address the constraints and weaknesses of the manufacturing sector.
\end{abstract}

Keywords: industrialization, premature deindustrialization, manufactures, manufacturing, structural change, growth, exports, sophistication of production.

\section{JEL classification: L60, O14, O25, F1.}

\footnotetext{
* Director, Centre for Research in Economics and Business, Lahore School of Economics.

** Research and Teaching Fellow, Centre for Research in Economics and Business, Lahore School of Economics.

The authors wish to acknowledge the excellent research assistance provided by Mehreen Irshad Butt, Zara Ejaz, and Abraham Shah, summer interns at the Centre for Research in Economics and Business.
} 


\section{Introduction}

It is evident that industry ${ }^{1}$ in Pakistan is in a state of crisis. The large-scale manufacturing (LSM) $)^{2}$ sector has grown, on average, by only 1.1 percent per annum in the last seven years (from 2008/09 to 2014/15; see Table A1 in the Appendix). This sector has experienced slowdowns in the past, but there have been only two other extended periods of low growth since 1950: first, in the 1970s (1971/72 to 1976/77) when LSM growth averaged only 2.1 percent per annum and, second, in the 1990s (1994/95 to 1999/2000) when LSM grew, on average, at 2.3 percent per annum.

However, there are several reasons why the current slowdown is of much greater concern. One, in the two previous instances, average annual growth was still about twice as high as it is now. Two, in the earlier two periods, growth in LSM picked up strongly in the seventh year; there are still no signs of a pickup in growth in the current period. Three, there is increasing evidence that the share of manufacturing in the economy is peaking in many developing countries at far earlier levels of income than it did in the industrialized countries - a phenomenon known as "premature deindustrialization" - and it is possible that the current slowdown in growth in industry in Pakistan may not just be a temporary problem.

The rest of the paper is organized as follows. Section 2 looks at growth trends in manufacturing and the economy. Section 3 summarizes the discussion in the literature on "premature deindustrialization." Section 4 looks at developments in Pakistan in the context of this discussion, analyzing the change in the structure of industry in terms of an industrial sophistication index. Section 5 concludes with a discussion of the prospects for industrial growth in Pakistan, and suggests broad guidelines for issues to be addressed in an industrial policy to reinvigorate the country's manufacturing sector.

\section{Trends in Growth}

We focus on the LSM subsector not only because it accounts for 80 percent of the manufacturing sector, but also because there is reasonable data available on the annual value added (VA) and on changes in

\footnotetext{
${ }^{1}$ In this paper, the words "industry" and "manufacturing" are used interchangeably.

2 In Pakistan, the manufacturing sector comprises two subsectors: LSM and small-scale manufacturing. LSM covers establishments registered under the Factories Act 1934 or those qualifying for registration (having ten or more employees). These include repair and service industries. Small-scale manufacturing includes all such manufacturing establishments not covered under LSM (Pakistan Bureau of Statistics, 2015).
} 
industrial structure over time. Figure 1 shows the (smoothed) growth rates of manufacturing, LSM, and gross domestic product (GDP) since 1960; LSM has been a leading sector of the economy over most of the period.

Figure 1: Growth trend: Smoothed series (three-year moving average)

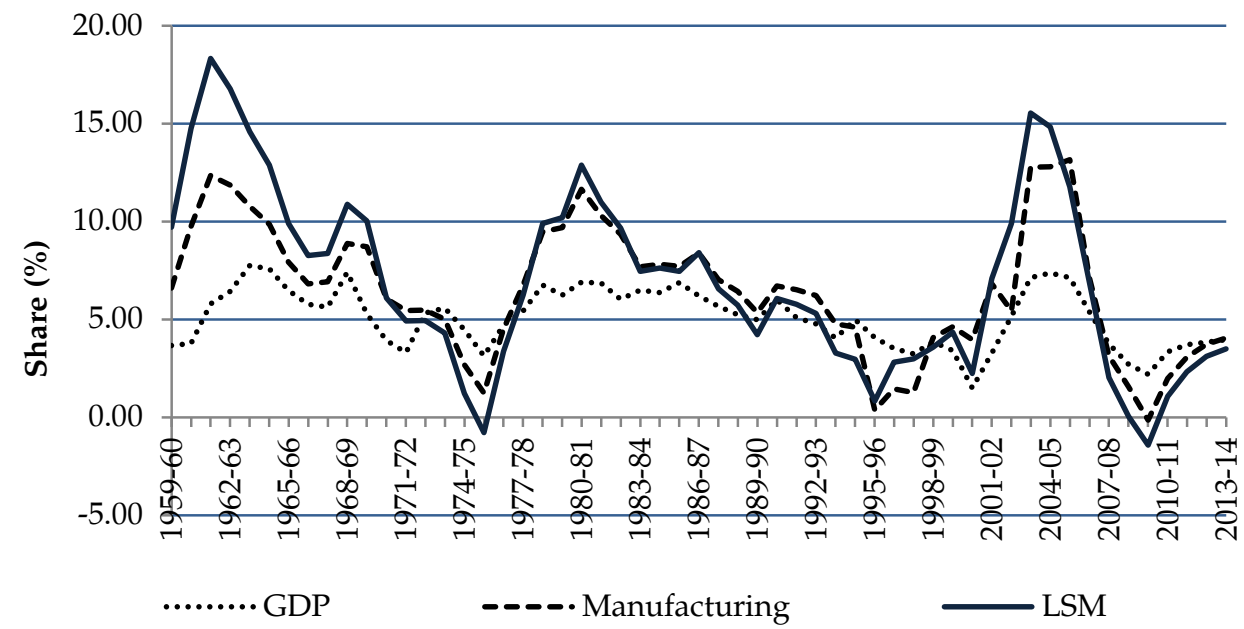

Note: The growth rate for $2000 / 01$ is estimated.

Source: Authors' calculations based on the following data: (i) for 1959-96: 50 years of Pakistan, vol. 1 (1947-1997) (http://www.pbs.gov.pk/sites/default/files/50_years statistics/vol1/3.pdf); (ii) for 1997-2015: Pakistan Economic Survey for various years.

There were three distinct cycles during this period with robust GDP growth: in the 1960s, 1980s, and mid-2000s; in each period, the LSM subsector was clearly the driver. However, there was some kind of structural break around 1990: in the 30 years prior to 1990, LSM (and GDP) growth averaged over 5 percent per annum throughout, except for six years in the 1970s, but in the 25 years since 1990, LSM (and GDP) growth has averaged over 5 percent per annum for only nine (eight) years, mostly in the 2000s.

This may be a coincidence, but it is worth noting that Pakistan abandoned its proactive industrial policy around 1990 and started a stopgo process of trade and economic liberalization at the behest of the international financial institutions (IFIs). However, trade liberalization policies do not seem to have had much long-term impact on Pakistan's exports, which, as a percentage of GDP (after reaching a peak in 1992) and world exports (after reaching a peak in 1996), have either declined or stagnated (see Figures 2 and 3). 
Figure 2: Exports as a percentage of GDP, Pakistan

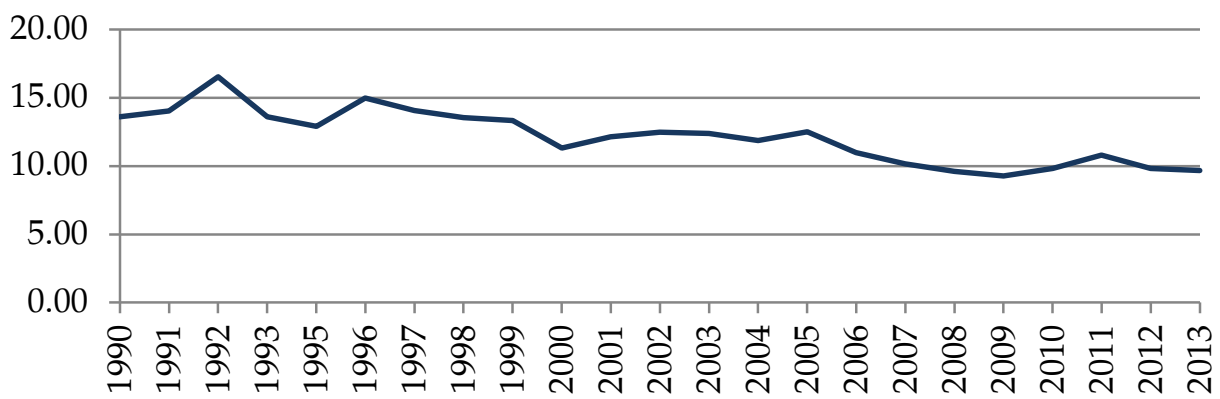

Source: Authors' calculations based on data from the United Nations Commodity Trade Statistics database (UN Comtrade) and trade map website, accessed 9 September 2015.

Figure 3: Exports as a percentage of world exports, Pakistan

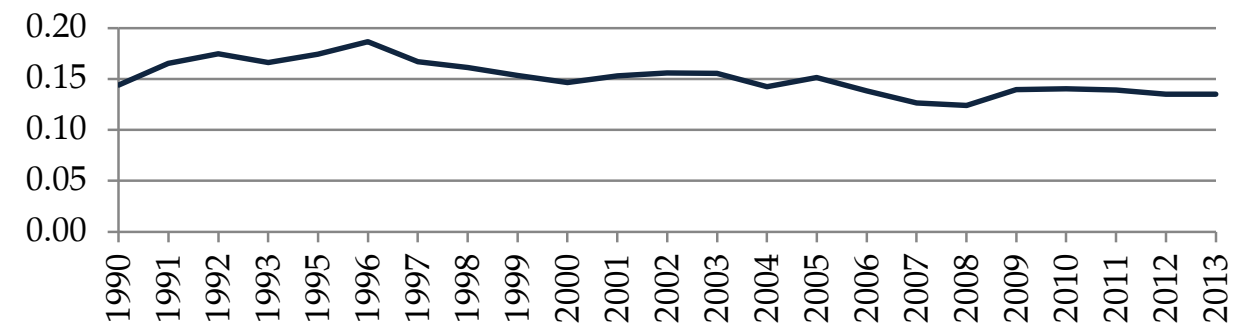

— Pak Exports as a \% of World Exports

Note: World export figures for 1990-93 have been estimated by extrapolating backward from 1994, using an index of the value of total world merchandise exports. Retrieved 17 September 2015 from https://www.wto.org/english/res_e/statis_e/its2001_e/stats2001_e.pdf

Source: Authors' calculations based on data from the United Nations Commodity Trade Statistics database (UN Comtrade) and trade map website, accessed 9 September 2015.

It is possible that, in the last 25 years, Pakistan has managed to get the worst of both worlds. By abandoning its active industrial policy, it lost the benefits of an economic focus on the development of the manufacturing sector, while its lackadaisical attempts at trade liberalization were not enough to start the process of export-oriented manufacturing and economic growth.

\section{Premature Deindustrialization}

Historically, the manufacturing sector was the engine of growth for advanced countries, absorbing most of the surplus labor from the agricultural sector. For a long period, the share of manufacturing in 
employment and output increased. However, as productivity growth in this sector rose faster than in the rest of the economy while the relative price of manufactures fell, the share of manufacturing in advanced countries ultimately declined.

This phenomenon was described as "deindustrialization" and was the subject of debate among economists for a long time. While deindustrialization is now considered normal for advanced developed countries, recent trends show that many developing countries have seen their manufacturing employment shares peak at far earlier levels of income than in advanced countries. This new occurrence is called "premature deindustrialization" - a term that seems to have been coined by Dasgupta and Singh (2006).

Rodrik (2015) argues that the conventional explanation for deindustrialization - that is, different rates of technological progress in manufacturing and other sectors of the economy, which relies crucially on adjustments in domestic relative prices - is not directly applicable to developing countries because they occupy a small share of the world market for manufactures, i.e., they are essentially price takers (pp. 3-4). The literature identifies a number of factors, including trade liberalization, globalization, the abandoning of industrial policies in most developing countries under the Washington Consensus, and the rise of China as a major industrial exporter, as reasons for "premature deindustrialization."3

A plausible story, according to Rodrik (2015), would be that, "as developing countries opened up to trade, their manufacturing sectors were hit by a double whammy. Those without a strong comparative advantage in manufacturing became net importers of manufacturing, reversing a long process of import substitution. In addition, developing countries 'imported' deindustrialization from the advanced countries, because they became exposed to the relative price trends produced in the advanced economies" (p. 4).

This process was probably compounded by the rise of China as an exporting powerhouse in the 1990s, the effect of which was twofold, with local manufacturers not only facing intense competition in export markets, but also losing consumers in domestic markets. In addition, as China's manufactured exports have expanded, it has grown as a destination for exports of primary products from developing countries,

${ }^{3}$ See, for example, Shafaeddin (2005), Wood and Mayer (2011), Jenkins and Barbosa (2012), Bogliaccini (2013), and Kim and Lee (2014). 
particularly in Latin America and Africa, and businesses there have shifted from manufacturing to the production of primary products for export to China - the so-called "Dutch Disease" effect (Kim \& Lee, 2014).

To sum up, there seem to be powerful economic forces that are adversely affecting the growth of the manufacturing sector in developing countries. This impact has not been uniform across regions: countries in Latin America and sub-Saharan Africa have been affected the worst, while those in Asia have mostly maintained a stronger manufacturing performance than would be expected on the basis of their income and demography (Rodrik, 2015, p. 12). That premature deindustrialization is not inevitable is reassuring. Historically, industrialization was considered synonymous with development and manufacturing was seen as the engine of growth. It makes it possible for workers in rural areas to move to higher-productivity jobs in factories, contributing to overall GDP growth because of the reallocation effect; manufacturing also tends to experience higher productivity growth.

All countries (except for a few resource-rich economies) that have achieved middle- or high-income status recently are associated with sustained growth in the manufacturing sector. However, Felipe, Mehta, and Rhee (2014) go further and ask if "today's developing economies can achieve high-income status without first building large manufacturing sectors" (p. 1). To answer this, they put together a large cross-country panel dataset. Their analysis shows that peak manufacturing employment shares in excess of 18-20 percent "strongly predict that an economy is rich; while peak shares below this threshold are near perfect predictors that an economy is not rich (i.e., manufacturing employment is necessary for becoming rich)" (p. 10). This could be particularly bad news for Pakistan (where the manufacturing employment share is around 14 percent) if the current slump in the manufacturing sector is an indicator of the onset of "premature deindustrialization" in the country.

\section{Pakistan's Experience}

This section examines changes in the structure of Pakistan's industry in terms of an industrial sophistication index.

\subsection{Is Pakistan in the Premature Deindustrialization Phase?}

The literature uses three broad measures to determine if and when a country is experiencing premature deindustrialization: (i) the share of 
manufacturing employment in total employment, (ii) manufacturing value added as a percentage of GDP in terms of constant prices, and (iii) manufacturing value added as a percentage of GDP at current prices. ${ }^{4}$

In cross-country analyses, the share of manufacturing employment appears to peak earlier than the real manufacturing value added (RMVA) share (see Felipe et al., 2014; Rodrik, 2015). For Pakistan, the manufacturing employment share is presented in Figure 4.

\section{Figure 4: Manufacturing sector employment as a share of total employment}

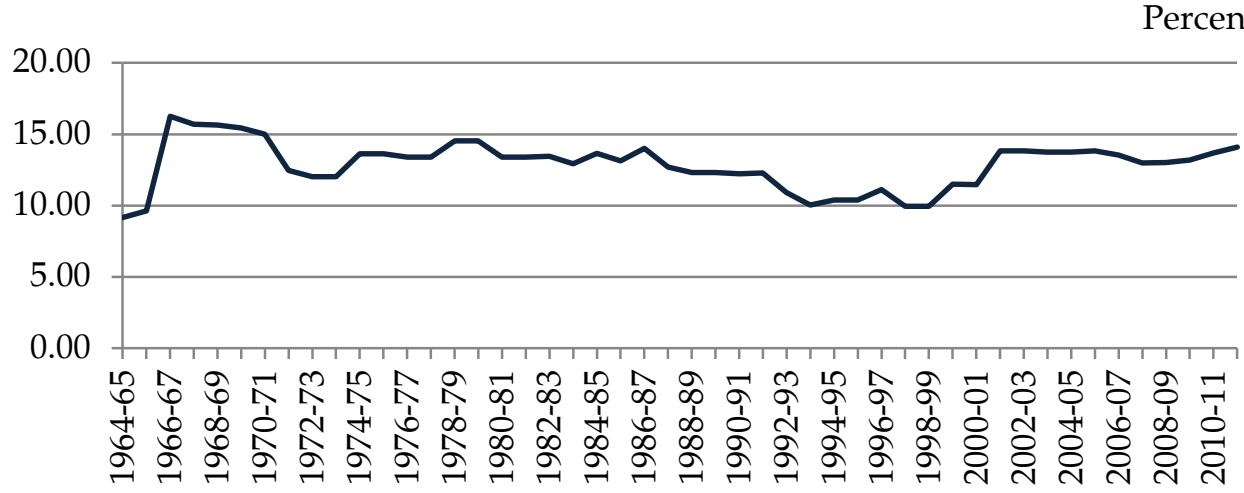

Source: Authors' calculations based on Pakistan country tables retrieved from http:/ /laborsta.ilo.org/STP/guest on 24 March 2015.

The share of manufacturing employment peaked at 16.3 percent in $1966 / 67$ as a consequence of rapid industrialization in the 1960s. After declining in the late 1960s and early 1970s, this share remained fairly stable at around 14 percent until 1986/87. It declined to a low of around 10 percent in 1993/94, at which level it stayed till 1998/99. The share of manufacturing employment then increased rapidly to 14 percent in 2001/02, where it stabilized. The slight upward trend since 2007/08, despite the low growth in the manufacturing sector, is puzzling. It seems that, while the manufacturing employment share has stabilized at well below the 18 percent threshold level established by Felipe et al. (2014), it has not begun to decline. It is worth noting that the peak manufacturing employment shares of China and India are in the 14-15 percent range, which are not much higher than the share in Pakistan.

\footnotetext{
${ }^{4}$ The peak in nominal manufacturing value added (NMVA) shares occurs somewhere in between the other two, but according to Rodrik (2015, p. 6), it is not clear if changes in the NMVA share have any economic significance per se. We do not discuss changes in the NVMA share in the paper, but these are presented in Figure A1 in the Appendix.
} 
The RMVA share for the period $1959 / 60$ to $2013 / 14$ is presented in Figure 5. There is a problem when looking at the trend over the entire period as the revisions in the base year in 1999/2000 and 2005/06 create discontinuities. As expected, there is a downward shift in the curve each time the base year is updated as the relative price of manufacturing declines over time. However, what is clear is that the RMVA share was increasing until 2007/08, when it peaked at 19 percent of GDP. Since then, the RMVA share has declined: according to the revised series (base year 2005/06), in 2013/14 it was 13.5 percent compared to 14.4 percent in $2007 / 08$, i.e., lower by 0.9 percentage points. ${ }^{5}$

Figure 5: Share in GDP at constant factor cost

Percent

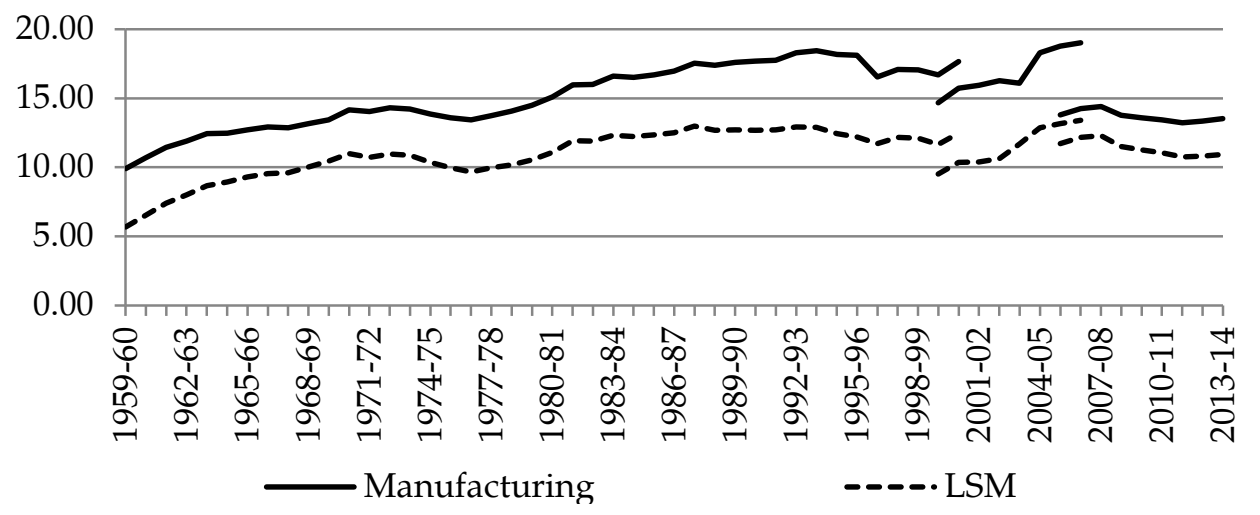

Note: The CMI's new survey re-estimated the size when the base year changed from $1999 / 2000$ to $2005 / 06$.

Source: Authors' calculations based on the following data: (i) for 1959-96: 50 years of Pakistan, vol. 1 (1947-1997) (http://www.pbs.gov.pk/sites/default/files/50_years statistics/vol1/3.pdf); (ii) for 1996-2001: Pakistan Statistical Year Book 2006 (Pakistan Bureau of Statistics); (iii) for 2001-10: Pakistan Statistical Year Book 2012 (Pakistan Bureau of Statistics); (iv) for 2010-14: Pakistan Economic Survey 2013-14.

During this period, the LSM share declined by 1.4 percentage points (from 12.3 percent in 2007/08 to 10.9 percent in 2013/14), indicating that small-scale and informal manufacturing activities were gaining at the expense of LSM. Since the former are far more laborintensive than LSM, this probably explains the increase in the manufacturing employment share since 2007/08 despite the slow growth in the sector (Figure 4).

${ }^{5}$ When adjusted for the price effect of the revision in the base year, it is only marginally below, i.e., 18.2 percent in 2013/14 against 19.0 percent in 2007/08 (about 5 percent lower). 
The evidence based on the shares of manufacturing employment and real value added is mixed. It seems that, unless there is another episode of rapid manufacturing growth as in the Musharraf period, the RMVA share has begun to decline. However, this is not yet reflected in the manufacturing employment share because the declining LSM share is being partially substituted by increasing small-scale and informal manufacturing activities, which are much more labor intensive. In other words, even if Pakistan is not already experiencing premature deindustrialization, it is on the brink of doing so.

\subsection{Trade Liberalization and Pakistan's Industrial Crisis}

It is argued that IFIs have played an important role in promoting trade liberalization in developing countries, primarily through the World Bank's structural adjustment lending and the IMF's stabilization programs. Pakistan received a number of such loans and credits in the early 1990s and again in the first half of the 2000s. Pakistan is not an open economy ${ }^{6}$ and probably has never been very open. However, despite IFI pressure to liberalize trade and many structural adjustment loans and IMF programs, Pakistan's trade openness has declined since the early 1990s.

Figure 6 plots Pakistan's trade openness ratio (exports plus imports of goods as a percentage of GDP). We see that, when Pakistan receives a World Bank structural adjustment loan or is under an IMF program, its trade openness increases, but as soon as the Bank loan is disbursed or the IMF program completed, its trade openness declines. For example, after increasing in the early 1990s, the trade-GDP ratio declines from 37.7 percent in 1992 to 24.9 percent in 2000. Again, after increasing in the first half of the 2000s, the trade-GDP ratio declines from 32.0 percent in 2005 to 29.7 percent in 2008. Since then, it has fluctuated between 25.9 and 29.4 percent.

\footnotetext{
${ }^{6}$ For example, in the "Trade Openness" component of the ICC Open Markets Index, Pakistan has the lowest score (1.8 out of a possible 6) among the 75 countries covered in the report (ICC, 2013, pp. 29-30).
} 
Figure 6: Trade openness

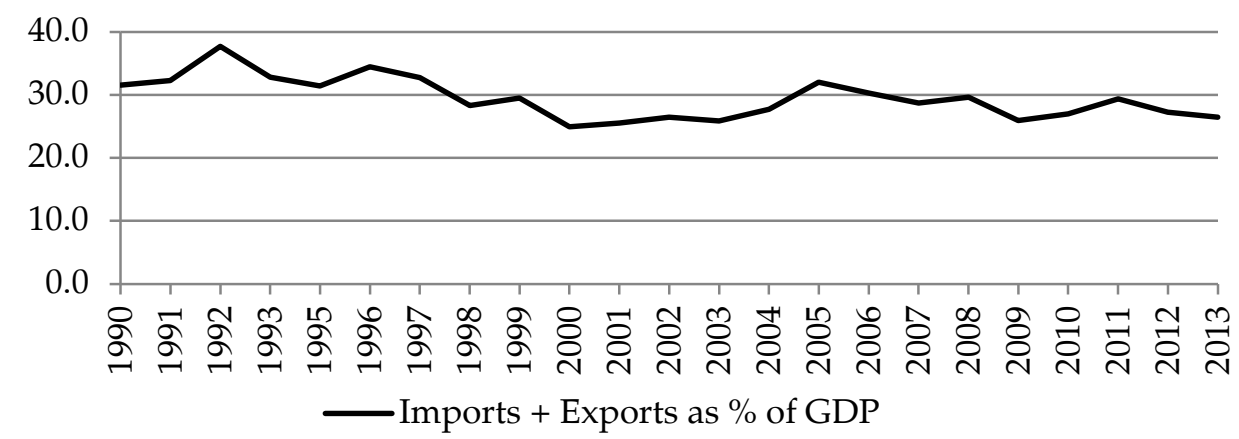

Source: Authors' calculations based on data from the United Nations Commodity Trade Statistics database (UN Comtrade) and trade map website, accessed 9 September 2015.

An alternative measure of the likely impact of trade liberalization on industry is to look at trends in the ratio of nonfood/nonoil (NFNO) imports to GDP since 1990. For this purpose, we take the 1980s as a benchmark, when Pakistan's NFNO imports were, on average, 11.3 percent of GDP. After increasing sharply in the early 1990s (to 14.3 percent in 1992/93), the NFNO imports-to-GDP ratio declines steadily for the rest of the decade (to 9.3 percent in 1999/2000) (see Table A2 in the Appendix). Thus, it seems that, on the external side, the cause of the slump in manufacturing in the 1990s was, if anything, the balance-ofpayments (BOP) constraint rather than increasing manufacturing imports.

After 2001/02, there is a surge in the NFNO imports-to-GDP ratio, driven both by a relaxation of the BOP constraint and trade liberalization, with a peak of 13.5 percent in 2005/06. However, this period is also one of high manufacturing growth and rising manufacturing employment and RMVA shares. Thus, one cannot say that trade liberalization adversely impacted the manufacturing sector during this period. Finally, post-2007, during the current manufacturing slump, the NFNO imports-to-GDP ratio declines from 13 percent in 2006/07 to 10 percent in 2012/13.

This implies that, in Pakistan, it is the BOP rather than excessive imports that has generally been the binding constraint as far as the manufacturing sector is concerned. Arguably, inadequate trade liberalization and an overvalued exchange rate $^{7}$ - compounded by power shortages - have prevented Pakistan's exports (including manufacturing) from expanding rapidly, increasing manufacturing growth and relaxing

${ }^{7}$ Pakistan's tradable sector suffers from the Dutch Disease effect because of workers' remittances, which were over 32 percent of total imports and 5.4 percent of GDP in 2012/13. 
the BOP constraint on a more sustainable basis (Ahmed, Hamid, \& Mahmud, 2015).

Imports from China have probably had a considerable impact on manufacturing in Pakistan. This is reflected in the increase in China's share of Pakistan's NFNO imports from 8.3 percent in 2000 to 25.6 percent in 2013 (see Table A3 in the Appendix). However, this does not give us a complete picture of the likely impact. Pakistan has a very special relationship with China, which includes tremendous support for Pakistan in defense and international forums, a preferential trading arrangement, and substantial Chinese investment in infrastructure. In return, Pakistan has been very relaxed in terms of scrutinizing imports from China, and this has opened up avenues for under-invoicing Chinese imports to evade import duties.

One estimate of this under-invoicing emerges when comparing "exports to Pakistan" as reported by China and "imports from China" as reported by Pakistan in the United Nations Commodity Trade dataset. Adjusted for this misreporting, Pakistan's NFNO imports from China as a share of total NFNO imports have increased from 10 percent in 2000 to 36.4 percent in 2013.

However, the impact of Chinese imports may not have been entirely negative. No doubt, local producers of competing manufactures would have been badly affected, but since the average import-to-GDP ratio in Pakistan has not increased since 1990, a large part of the increase in Chinese imports was at the expense of other countries. As far as these imports are concerned, consumers are certainly better off, but also a number of industries in Pakistan have gained because of access to restricted or high-duty imports of raw materials at reasonable prices. The motorcycle industry, manufacturers of white goods, assemblers of electronic goods, and exporters of sportswear and footballs, to name a few, have all benefited considerably from cheap imports from China.

Thus, Pakistan's manufacturing industry is in crisis not so much because of trade liberalization, but because of weaknesses in its internal policies. These are discussed by one of the authors elsewhere, but to summarize, they include: a disproportionate tax burden on manufacturing compared to other sectors, a restrictive and nontransparent trade regime, an overvalued exchange rate, and extensive gas and power shortages (see Ahmed et al., 2015; Ahmed, Mahmud, Hamid, \& Rahim, 2010; Hamid \& Hayat, 2012). 
A reason for the lack of a conducive environment for the manufacturing sector is that Pakistan has not had a proactive industrial policy since the 1990s. Industrial policy is also needed to nudge industry in the country to move up the technology or sophistication ladder, which is essential if the manufacturing sector is to be an engine of growth over an extended period. Next, we look at what has been happening to the structure of industry in Pakistan over the last two decades or so.

\subsection{Structural Change in Industry}

A key element in the success of the new industrializers, particularly in East Asia, has been their ability to move up to more sophisticated industries as rising labor costs eroded their competitiveness in the simpler and more labor-intensive industries. Thus, structural change in an industry can be a good leading indicator of the likelihood of a country being able to sustain industrial growth over an extended period of time.

In this section, we look at how the structure of industry in Pakistan has changed in the last 25 years or so. First, we discuss the change in structure in terms of the standard industrial classifications given in the Census of Manufacturing Industries (CMI). Given that any conclusions we draw on this basis - with regard to whether the observed changes in the share of different industries represent a movement up the technology ladder - will be subjective, we also look at the change in industrial structure based on the sophistication index scores developed by Lall, Weiss, and Zhang (2005).

Data on the VA shares of the top 16 industries at the 2-digit level for Pakistan, Sindh, and Punjab from 1990/91 to 2005/06 (2010/11 for Punjab) are presented in Tables A4 to A6 in the Appendix. The top three industries in 2005/06 were textiles, food products and beverages, and chemicals and chemical products. Their combined VA share was 57.5 percent, which has hardly changed since 1990/91, when it was 56.9 percent. There were, however, some positive changes within two of these industries with higher VA activities such as fabrics and finishing gaining at the expense of spinning (in textiles), and vegetable oils and dairy products gaining at the expense of sugar (in food and beverages).

At the 2-digit level, the main gainers (i.e., an increase of over 0.5 percent in their VA share) during this period were wearing apparel (from 1.4 to 4.7 percent), petroleum (from 3 to 4.7 percent), motor vehicles (from 2 to 4.5 percent), paper and paper products (from 1.6 to 2.5 percent), and other transport equipment (from 0.6 to 1.5 percent). The main losers 
during this period were basic metals (from 5.6 to 4 percent) and electrical machinery (from 4.1 to 1.9 percent). 8 Thus, the change over this 15 -year period (1990 to 2005) was relatively small, but on the whole, largely positive, with higher VA items such as fabrics, garments, petroleum, and vehicles increasing their share. There was some downside, such as the decline in basic metals and electrical machinery.

Most of the industry in Pakistan is located in Sindh and Punjab, accounting for 88 percent of the LSM value added in 2005/06. It is interesting to see that the industrial structure in the two provinces is quite different. In Punjab, agriculture and resource-based industries, such as textiles (excluding silk and art silk textiles), food and beverages, wearing apparel, cement, and paper dominate, accounting for over 61 percent of the value added in 2005/06. ${ }^{9}$ In Sindh, however, the industrial structure is more technology-intensive with chemicals, petroleum, motor vehicles, basic metals, machinery (both general and electrical), and other transport equipment accounting for over 51 percent of the value added in 2005/06.10 These differences between the two provinces seem to have increased from 1990/91 to 2005/06: in 1990/91, the share of agriculture and resource-based industries in Punjab was less than 50 percent and that of technology-intensive products in Sindh was around 42 percent.

Unfortunately, the data on the structure of industry for Pakistan as a whole is almost a decade old, but the CMI for Punjab for 2010/11 shows a slight trend reversal in the increasing concentration on agriculture and resource-based industries, whose VA share declined from under 58 percent (adjusted) to under 57 percent (adjusted). ${ }^{11}$ However, there was no increase in the VA share of technology-intensive industries, which remained around 22 percent. The structural change in Pakistan's industry seems to have been slow, largely because Sindh and Punjab have very different industrial structures. Thus, as the trend has been one of increasing concentration in their respective areas of strength, any changes in the two provinces have tended to cancel each other out.

\footnotetext{
${ }^{8}$ The decline in tobacco products seems to be very large (from 6.4 to 2.2 percent), but this is an overstatement due to the likely underreporting of tobacco products in Punjab in 2005/06. The share of tobacco products in Punjab was abnormally low in 2005/06 (0.8 against 7.2 percent in 2000/01 and 8.1 percent in 2010/11), possibly because the CMI for 2005/06 is missing the largest cigarette manufacturer in the country, Pakistan Tobacco Company, whose main production facilities are located in Punjab.

${ }^{9}$ This is probably an overstatement (see footnote above). If we adjust for it, the share of agriculture and resource-based industries drops to around 58 percent.

${ }^{10}$ The share of these industries in Punjab in 2005/06 was only 22 percent.

${ }^{11}$ The 2005/06 share was adjusted for underreporting in tobacco products and the 2010 share has been adjusted for the missing data on silk and art silk textiles, which accounted for about 7 percent of the CMI value added in Punjab in 2005/06.
} 
We have discussed the structure of industry and changes in it in terms of agricultural and resource-based industries on the one hand and technology-intensive industries on the other, assuming that movements from the former to the latter imply an upgrading of industrial structure. However, this is a rather crude and not very satisfactory basis for analyzing structural change in industry for a country. Most other studies discuss the upgrading of industrial structure in developing countries based on an analysis of the structure of a country's exports (see Lall et al., 2005; Hausmann, Hwang, \& Rodrik, 2005; Hausmann \& Klinger, 2007). On this basis, Pakistan's exports have not been upgraded very much in terms of technology or sophistication. Hausmann et al. (2005) have developed a methodology that uses the weighted average of the per capita GDP of the countries exporting that commodity (denoted by PRODY) and the weighted average income level of a country's exports basket (denoted by EXPY) to look at changes in the structure of a country's exports.

Applying this methodology to Pakistan and comparing exports in 1986 and 2004, Felipe (2007, p. 21) states that, "the country is 'stuck' in exports that are being exported by ever poorer countries. And, the income level of Pakistan's exports, denoted by EXPY, a proxy for its exports complexity... has not shown the increase expected from a country that is undergoing the kind of structural transformation that leads to faster growth. Pakistan's index in $1986(4,664)$ is the same as in $2004(4,628) . "$

Applying the same methodology somewhat later, Reis and Taglioni (2013) write that, "countries that have a more sophisticated export basket, proxied by a measure named EXPY, enjoy accelerated subsequent growth while those with less sophisticated export baskets tend to lag behind. In a sample of 100 developing countries ... Pakistan lies below the 'average' regression line, implying that its export basket is 'poorer' than it should be, given its income per capita." They go on to say that, "in terms of sophistication, in the past two decades Pakistan's export basket has not undergone as stark an improvement as its Asian peers" (p. 14).

A country's export structure may be a reasonable proxy for the structure of its industry, but for a country whose exports (manufacturing exports) are such a small percentage of GDP (VA in the manufacturing sector), it would help if one could look at the industrial structure in terms of sophistication directly. We adapt and apply the industrial sophistication index ${ }^{12}$ developed by Lall et al. (2005) to the Pakistan Standard Industrial

${ }^{12}$ Lall et al. (2005) describe their method for calculating the sophistication index as follows: "At the product level, the sophistication measure uses data on exports by all countries (separately) and 
Classifications in the CMI. The structure of industry in Pakistan, Sindh, and Punjab is calculated on the basis of the sophistication index score and presented in Tables A7 to A9 in the Appendix.13

Given the CMI's variability of coverage in different years and across provinces, we focus on the overall picture and do not discuss yearto-year changes. For the purposes of our discussion, summary tables on the structure of industry on the basis of sophistication levels ${ }^{14}$ are presented in Tables 1 to 3. The performance of Pakistan's industry in terms of upgrading seems to have been very poor. One, instead of increasing, industry in Pakistan (and in Punjab) seems to be declining in sophistication over time. Two, the structure shows a complete lack of dynamism with there being hardly any movement between sophistication levels during 1990/91 to 2005/06 (2010/11 for Punjab). Three, about 50 percent of the VA share of the industry is at the lowest level of sophistication.

\section{Table 1: Summary of industrial sophistication, Pakistan}

\begin{tabular}{lrrrr} 
& Percentage share of LSM in total manufacturing \\
\hline & $\mathbf{1 9 9 0 / 9 1}$ & $\mathbf{1 9 9 5 / 9 6}$ & $\mathbf{2 0 0 0 / 0 1}$ & $\mathbf{2 0 0 5 / 0 6}$ \\
\hline Total sophistication level 1 & 2.1 & 1.9 & 1.5 & 2.4 \\
Total sophistication level 2 & 21.4 & 22.3 & 17.1 & 20.2 \\
Total sophistication level 3 & 2.5 & 2.2 & 2.9 & 1.9 \\
Total sophistication level 4 & 16.6 & 15.0 & 16.8 & 15.0 \\
Total sophistication level 5 & 8.7 & 11.0 & 15.1 & 9.2 \\
Total sophistication level 6 & 48.8 & 47.6 & 46.6 & 51.2 \\
Average sophistication score & 68.9 & 66.5 & 65.9 & 63.0 \\
\hline
\end{tabular}

Source: Authors' calculations based on data from the Census of Manufacturing Industries for various years. Sophistication scores obtained from Lall, Weiss, and Zhang (2005).

the income level of each exporter. The sophistication score is calculated for each product by taking the weighted average (the weights being each country's share of world exports) of exporter incomes. The scores are normalized to yield an index ranging from zero to 100 " (p. 8).

${ }^{13}$ The methodology for the preparation of these tables is given in the Appendix.

${ }^{14}$ Lall et al. (2005) divide all the commodities traded into six levels on the basis that the total traded value of commodities at each level is about the same. These levels are numbered from 1 to 6 , with the most sophisticated products being at level 1 and the least sophisticated at level 6. Summary tables provide average sophistication scores for Pakistan and the provinces at each of the six levels. 
Table 2: Summary of industrial sophistication, Sindh

\begin{tabular}{lrrrr} 
& Percentage share of LSM in total manufacturing \\
\hline & $\mathbf{1 9 9 0 / 9 1}$ & $\mathbf{1 9 9 5 / 9 6}$ & $\mathbf{2 0 0 0 / 0 1}$ & $\mathbf{2 0 0 5 / 0 6}$ \\
\hline Total sophistication level 1 & 1.3 & 1.7 & 0.7 & 1.9 \\
Total sophistication level 2 & 20.1 & 18.7 & 24.8 & 26.7 \\
Total sophistication level 3 & 0.6 & 0.9 & 1.0 & 1.5 \\
Total sophistication level 4 & 20.7 & 22.3 & 19.4 & 16.0 \\
Total sophistication level 5 & 11.5 & 11.6 & 19.3 & 13.7 \\
Total sophistication level 6 & 45.8 & 44.9 & 34.8 & 40.3 \\
Average sophistication score & 65.4 & 63.3 & 67.6 & 65.5 \\
\hline
\end{tabular}

Source: Authors' calculations based on data from the Census of Manufacturing Industries for various years. Sophistication scores obtained from Lall, Weiss, and Zhang (2005).

\section{Table 3: Summary of industrial sophistication, Punjab}

\begin{tabular}{lrrrrr} 
& Percentage share of LSM in total manufacturing \\
\hline & $\mathbf{1 9 9 0 / 9 1}$ & $\mathbf{1 9 9 5 / 9 6}$ & $\mathbf{2 0 0 0 / 0 1}$ & $\mathbf{2 0 0 5 / 0 6}$ & $\mathbf{2 0 1 0 / 1 1}$ \\
\hline Total sophistication level 1 & 4.9 & 1.8 & 2.2 & 2.6 & 2.1 \\
Total sophistication level 2 & 24.0 & 23.3 & 16.5 & 14.1 & 17.6 \\
Total sophistication level 3 & 1.5 & 3.5 & 4.2 & 1.5 & 4.2 \\
Total sophistication level 4 & 13.0 & 13.5 & 13.2 & 14.7 & 16.8 \\
Total sophistication level 5 & 5.9 & 5.6 & 10.0 & 5.2 & 7.0 \\
Total sophistication level 6 & 50.7 & 52.4 & 53.9 & 61.8 & 52.2 \\
Average sophistication score & 68.5 & 65.0 & 63.6 & 60.9 & 63.7 \\
\hline
\end{tabular}

Source: Authors' calculations based on data from the Census of Manufacturing Industries for various years. Sophistication scores obtained from Lall, Weiss, and Zhang (2005).

There are considerable differences in provincial industrial structures and changes in them over time. In Sindh, in 2005/06, 40 percent of the VA share of industry is at the lowest sophistication level compared to 52 percent in Punjab in 2010/11.15 The VA share of the top three sophistication levels is also much higher in Sindh (30 percent in 2005/06) than in Punjab (24 percent in 2010/11). In terms of trends, the VA share of the top three levels increased in Sindh by 8 percentage points between 1990/91 and 2005/06, but in Punjab it actually declined by 6 percentage points from $1990 / 91$ to $2010 / 11 .{ }^{16}$ Thus, the analysis based on

15 Punjab's average sophistication score is understated and the share of level 6 is overstated in 2005/06 because of the underreporting of tobacco products discussed in the previous footnote. For comparison purposes, therefore, we use Punjab's 2010/11 structure.

16 There is a sharp fall in the 1990s and then a marginal improvement in the 2000s, with the VA share increasing from 23 percent in 2000/01 to 24 percent in 2010/11. 
sophistication levels shows that industry in Sindh is far more sophisticated than in Punjab; it is also more dynamic, with considerable upgrading taking place over the period. In Punjab, the slight improvement in the 2000s is overwhelmed by the massive downgrading of industry in the 1990s.

This analysis of industrial structure on the basis of sophistication of industry tends to substantiate the conclusion that industry in Pakistan has stagnated as a whole, based on an analysis of the export data. Our finding of modest upgrading of industry on the basis of the Standard Industrial Classification may have been too optimistic. It also confirms that industry in Sindh is more sophisticated than in Punjab, and there was substantial upgrading in Sindh's industry in the period 1990/91 to 2005/06.

However, because of the poor law and order situation since 2007 in Karachi, where most of the industry in Sindh is located, it is possible that the process of industrial upgrading in the province seen earlier may not have been sustained. Also because of poor law and order, it is likely that industrial growth in Sindh since 2007 has been even lower than in Punjab. Thus, given the difference in levels of sophistication of industry in the two provinces, it is likely that the average level of sophistication of industry in the country as a whole may be lower today than it was in 2005/06.

\section{Conclusion}

Manufacturing growth has played a critical role in the development of the advanced countries as well as in almost all developing countries that have succeeded in closing the income gap with the former. Thus, "premature deindustrialization" blocks off the main avenue for a country to catch up with advanced economies.

As a result of stagnation in manufacturing since 2007, Pakistan is on the brink, if not already in the process, of premature deindustrialization. It will not be easy to revitalize industrial growth in Pakistan: its industrial structure in terms of sophistication is not only below that of other countries at its level of per capita income, but it has also been stuck at this low level of sophistication for a long time. On the positive side, the industrial structure in Sindh is much more dynamic and has continued to upgrade since 1990/91. Therefore, if industrial growth in Sindh revives, it could lead the industrial upgrading process in the country as a whole.

Some positive recent developments give hope that Pakistan's manufacturing growth might revive and once again achieve the levels 
reached in previous high-growth periods. Among these, probably the most important development is the military's recognition that fundamentalism and religious terrorism pose a threat to the survival of Pakistan, and the fresh purpose with which the fight against terrorism is being conducted. The direct benefits of the improvement in internal security are already visible, particularly in Karachi, and if this fight is sustained, it should result in a sea change in Pakistan's economic environment.

The second significant development is the announcement of the China-Pakistan Economic Corridor investment package of about US\$ 46 billion. If implemented even partially, this initiative will have many positive impacts on the economy - boosting economic activity, significantly reducing (if not eliminating) the crippling power shortages, and changing economic sentiments in and about Pakistan, which could boost both domestic and foreign direct investment in the country. These two developments complement each other and could potentially initiate a "virtuous" circle of investment and growth lasting many years.

To take full advantage of these developments to revitalize manufacturing growth in the country, a number of measures need to be implemented. Pakistan should once again adopt a proactive industrial policy to address the constraints and weaknesses of the manufacturing sector. Pakistan abandoned any serious attempt at industrial policy in the late 1980s, undoubtedly influenced by the policy advice of donors based on the Washington Consensus. However, there is now growing realization even in the international community that industrial policy has a role to play in developing countries (see Felipe, 2007; Hausmann \& Rodrik, 2006; Hausmann et al., 2005; Rodrik, 2004, 2014), and it is important that Pakistan should develop and implement an industrial policy.

Some of the key aims of this industrial policy should be, first, to provide manufacturing with a level playing field, particularly with regard to the incidence of taxation. Pakistan faces a chronic problem of a low tax-to-GDP ratio and inability to broaden the tax base. Since it is easier to collect taxes from manufacturing than other sectors (such as wholesale and retail trade, real estate, transportation, and agriculture), there is a tendency on the part of the government to impose additional taxes on manufacturing whenever there is pressure to increase tax revenues. Predatory tax officials also find it easier to extract rents from factories than shops, restaurants, construction sites, or bus and truck operators. Since investment decisions are influenced by after-tax returns and many of the other sectors are generally outside the tax net, very little 
new investment is going into manufacturing. There is clearly a need to readdress this imbalance.

Second, it is necessary to prioritize manufacturing in the management of power and gas shortages in particular and infrastructure shortages in general. In recent years, the power and gas shortages and resulting load shedding have had a disproportionate adverse impact on the manufacturing sector, both in terms of higher costs and greater uncertainty in production planning (Hamid, Nabi, \& Zafar, 2014). While it may be difficult to eliminate these shortages in the short term (though the present crisis has been ongoing since 2007), better demand management that takes into account the needs of the manufacturing sector ${ }^{17}$ could mitigate this negative impact.

Third, it is necessary to develop some way of compensating manufacturing exporters for Pakistan's chronic exchange rate overvaluation. As mentioned earlier, large workers' remittances have meant that Pakistan suffers from a chronically overvalued exchange rate as far as the tradable sectors are concerned - the so-called Dutch Disease effect. In recent years, this has been compounded by the government's stated strong exchange rate policy, which has caused Pakistan's real effective exchange rate to appreciate in the last two years. ${ }^{18}$ It will be difficult to sustain a high growth rate in manufacturing unless steps are taken to insulate the sector from the Dutch Disease effect.

Finally, to help manufacturing in Pakistan to move up the sophistication curve, it is necessary for the government to focus on developing the required technical and skilled manpower. The Punjab government is pursuing some innovative approaches in the area of skills development, but there is a need for such initiatives on a countrywide level as well as for the development of a larger technical and engineering workforce. If a comprehensive industrial policy that addresses the above issues is developed and implemented in an economic environment that, as mentioned, could be quite positive, the manufacturing sector could once again drive economic growth in Pakistan.

\footnotetext{
${ }^{17}$ For example, eight to ten hours a day of continuous supply is far better than 16 hours a day of supply, but on a schedule of a one-hour shutdown every two hours.

18 According to World Bank (2015) data, Pakistan's real effective exchage rate apreciated from 102 in 2013 (100 in 2010) to 110 in 2014 (http://data.worldbank.org/indicator/PX.REX.REER).
} 


\section{References}

Ahmed, H., Hamid, N., \& Mahmud, M. (2015). Exports: Lessons from the past and the way forward. In R. Amjad \& S. J. Burki (Eds.), Pakistan: Moving the economy forward (pp. 135-170). New Delhi: Cambridge University Press.

Ahmed, H., Mahmud, M., Hamid, N., \& Rahim, T. (2010). A strategy for reversing Pakistan's dismal export performance (Policy Paper No. 0110). Lahore: Centre for Research in Business and Economics.

Bogliaccini, J. A. (2013). Trade liberalization, deindustrialization, and inequality: Evidence from middle-income Latin American countries. Latin American Research Review, 48(2), 79-105.

Dasgupta, S., \& Singh, A. (2006). Manufacturing, services and premature deindustrialization in developing countries: A Kaldorian analysis (Research Paper No. 2006/49). Helsinki: UNU-WIDER.

Felipe, J. (2007). A note on competitiveness and structural transformation in Pakistan (ERD Working Paper No. 110). Manila: Asian Development Bank.

Felipe, J., Mehta, A., \& Rhee, C. (2014). Manufacturing matters... but it's the jobs that count (Economics Working Paper No. 420). Manila: Asian Development Bank.

Hamid, N., \& Hayat, S. (2012). The opportunities and pitfalls of Pakistan's trade with China and other neighbors [Special edition]. Lahore Journal of Economics, 17, 271-292.

Hamid, N., Nabi, I., \& Zafar, R. (2014). The textiles and garments sector: Moving up the value chain [Special edition]. Lahore Journal of Economics, 19, 283-306.

Hausmann, R., \& Klinger, B. (2007). The structure of the product space and the evolution of comparative advantage (CID Working Paper No. 146). Cambridge, MA: Harvard University.

Hausmann, R., \& Rodrik, D. (2006). Doomed to choose: Industrial policy as predicament. Unpublished manuscript, Harvard University, Cambridge, MA. 
Hausmann, R., Hwang, J., \& Rodrik, D. (2005). What you export matters (CID Working Paper No. 123). Cambridge, MA: Harvard University.

International Chamber of Commerce. (2013). ICC Open Markets Index 2013. Paris: ICC Research Foundation.

Jenkins, R., \& Barbosa, A. (2012). Fear for manufacturing? China and the future of industry in Brazil and Latin America. The China Quarterly, 209, 59-81.

Kim, C. S., \& Lee, S. (2014). Different paths of deindustrialization: Latin American and Southeast Asian countries from a comparative perspective. Journal of International and Area Studies, 21(2), 65-81.

Lall, S., Weiss, J., \& Zhang, J. (2005). The 'sophistication' of exports: A new measure of product characteristics (QEH Working Paper No. 123). Oxford: Oxford University.

Pakistan Bureau of Statistics. (2015). Industry [Webpage]. Retrieved 13 September 2015, from http:/ / www.pbs.gov.pk/content/industry

Pakistan, Ministry of Finance. (2015). Pakistan economic survey 2014-15. Retrieved from http://www.finance.gov.pk/survey_1415.html

Reis, J. G., \& Taglioni, D. (2013). Pakistan: Reinvigorating the trade agenda (Policy Paper Series on Pakistan No. PK 15/12). Washington, DC: World Bank.

Rodrik, D. (2004). Industrial policy for the twenty-first century. Unpublished manuscript, Harvard University, Cambridge, MA.

Rodrik, D. (2014). The past, present, and future of economic growth. In F. Allen, J. R. Behrman, N. Birdsall, S. Fardoust, ... A. Subramanian (Eds.), Towards a better global economy: Policy implications for citizens worldwide in the 21st century (chap. 2). New York, NY: Oxford University Press.

Rodrik, D. (2015). Premature deindustrialization (Working Paper No. 20935). Cambridge, MA: National Bureau of Economic Research.

Shafaeddin, S. M. (2005). Trade liberalization and economic reform in developing countries: Structural change or deindustrialization? 
(Discussion Paper No. 179). Geneva: United Nations Conference on Trade and Development.

State Bank of Pakistan. (n.d.). Economic data [Database]. Available at http://www.sbp.org.pk/ecodata/index2.asp\#real.

United Nations Statistics Division. (2015). UN comtrade [Database]. Available at http:/ / comtrade.un.org/data/

Wood, A., \& Mayer, J. (2011). Has China deindustrialized other developing countries? Review of World Economics, 147(2), 325-350.

World Bank. (2015). Data [Database]. Available at http:/ / data.worldbank.org/indicator/PX.REX.REER. 


\section{Appendix}

Figure A1: Share of GDP at current factor cost (percent)

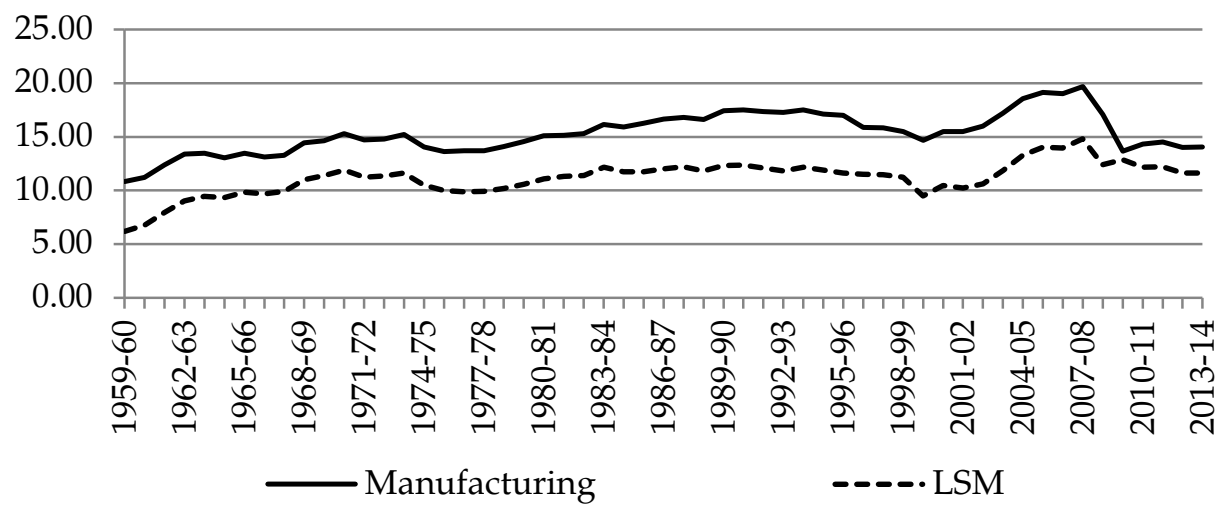

Source: Authors' calculations based on the following data: (i) for 1959-96: 50 years of Pakistan, vol. 1 (1947-1997) (http://www.pbs.gov.pk/sites/default/files/50_years statistics/vol1/3.pdf); (ii) for 1996-2001: Pakistan Statistical Year Book 2006 (Pakistan Bureau of Statistics); (iii) for 2001-10: Pakistan Statistical Year Book 2012 (Pakistan Bureau of Statistics); (iv) for 2010-14: Pakistan Economic Survey 2013-14.

Table A1: LSM, manufacturing, and GDP growth rates

\begin{tabular}{ccccc} 
& & \multicolumn{2}{c}{ Percent, at constant factor cost } \\
\hline Base year & Year & LSM growth & Manuf. growth & GDP growth \\
\hline $1980 / 81$ & $1949 / 50$ & & & \\
& $1950 / 51$ & 23.4 & 8.4 & 3.8 \\
& $1951 / 52$ & 18.8 & 7.7 & -1.7 \\
$1952 / 53$ & 23.7 & 10.0 & 1.9 \\
$1953 / 54$ & 28.6 & 13.0 & 10.0 \\
$1954 / 55$ & 24.2 & 12.3 & 1.7 \\
$1955 / 56$ & 17.4 & 10.0 & 3.5 \\
$1956 / 57$ & 8.1 & 5.4 & 2.9 \\
$1957 / 58$ & 4.9 & 3.7 & 2.6 \\
$1958 / 59$ & 5.6 & 4.2 & 5.5 \\
$1959 / 60$ & 2.7 & 2.5 & 0.9 \\
$1960 / 61$ & 20.3 & 12.8 & 4.7 \\
$1961 / 62$ & 19.9 & 13.3 & 5.6 \\
$1962 / 63$ & 15.7 & 11.2 & 7.0 \\
$1963 / 64$ & 15.5 & 11.3 & 6.6 \\
$1964 / 65$ & 13.0 & 9.9 & 9.5 \\
$1965 / 66$ & 10.8 & 8.6 & 6.7 \\
$1966 / 67$ & 6.7 & 5.6 & 3.7 \\
\hline
\end{tabular}




\begin{tabular}{|c|c|c|c|c|}
\hline Base year & Year & LSM growth & Manuf. growth & GDP growth \\
\hline & $1967 / 68$ & 7.6 & 6.4 & 6.9 \\
\hline & $1968 / 69$ & 10.6 & 8.6 & 6.1 \\
\hline & $1969 / 70$ & 14.0 & 11.3 & 9.1 \\
\hline & $1970 / 71$ & 6.2 & 6.4 & 1.0 \\
\hline & $1971 / 72$ & -0.5 & 1.3 & 2.1 \\
\hline & $1972 / 73$ & 9.2 & 8.7 & 6.7 \\
\hline & $1973 / 74$ & 6.1 & 6.4 & 7.0 \\
\hline & $1974 / 75$ & -1.6 & 0.5 & 3.3 \\
\hline & $1975 / 76$ & -0.6 & 1.4 & 3.4 \\
\hline & $1976 / 77$ & -0.2 & 1.8 & 2.8 \\
\hline & $1977 / 78$ & 10.9 & 10.2 & 7.8 \\
\hline & $1978 / 79$ & 7.8 & 8.0 & 5.6 \\
\hline & $1979 / 80$ & 11.0 & 10.3 & 6.9 \\
\hline & $1980 / 81$ & 11.5 & 10.6 & 6.2 \\
\hline & $1981 / 82$ & 15.7 & 13.8 & 7.6 \\
\hline & $1982 / 83$ & 6.6 & 7.0 & 6.8 \\
\hline & $1983 / 84$ & 7.7 & 7.9 & 4.0 \\
\hline & $1984 / 85$ & 8.0 & 8.1 & 8.7 \\
\hline & $1985 / 86$ & 7.3 & 7.5 & 6.4 \\
\hline & $1986 / 87$ & 7.2 & 7.5 & 5.8 \\
\hline & $1987 / 88$ & 10.6 & 9.9 & 6.4 \\
\hline & $1988 / 89$ & 2.4 & 4.0 & 4.8 \\
\hline & $1989 / 90$ & 4.7 & 5.7 & 4.6 \\
\hline & $1990 / 91$ & 5.4 & 6.2 & 5.6 \\
\hline & $1991 / 92$ & 7.9 & 8.0 & 7.7 \\
\hline & $1992 / 93$ & 4.1 & 5.4 & 2.3 \\
\hline & $1993 / 94$ & 4.1 & 5.5 & 4.5 \\
\hline & $1994 / 95$ & 1.7 & 3.6 & 5.2 \\
\hline & $1995 / 96$ & 3.1 & 4.8 & 5.2 \\
\hline & $1996 / 97$ & -2.1 & -6.8 & 2.0 \\
\hline & $1997 / 98$ & 7.6 & 6.9 & 3.5 \\
\hline & $1998 / 99$ & 3.6 & 4.1 & 4.2 \\
\hline & $1999 / 00$ & 0.0 & 1.5 & 3.9 \\
\hline & $2000 / 01$ & 9.5 & 8.2 & 2.2 \\
\hline \multirow[t]{6}{*}{$1999 / 2000$} & $1999 / 00$ & $\sim$ & $\sim$ & $\sim$ \\
\hline & $2000 / 01$ & 11.0 & 9.3 & 2.0 \\
\hline & $2001 / 02$ & 3.5 & 4.5 & 3.1 \\
\hline & $2002 / 03$ & 7.2 & 6.9 & 4.7 \\
\hline & $2003 / 04$ & 18.1 & 4.9 & 7.5 \\
\hline & $2004 / 05$ & 19.9 & 25.5 & 9.0 \\
\hline
\end{tabular}




\begin{tabular}{ccccc}
\hline Base year & Year & LSM growth & Manuf. growth & GDP growth \\
\hline $2005 / 06$ & 8.3 & 8.7 & 5.8 \\
$2006 / 07$ & 8.7 & 8.3 & 6.8 \\
$2007 / 08$ & 4.0 & 4.8 & 3.7 \\
$2008 / 09$ & -8.1 & -3.6 & 1.7 \\
$2009 / 10$ & 4.8 & 5.5 & 3.1 \\
\hline $2005 / 06$ & $2005 / 06$ & $\sim$ & $\sim$ & $\sim$ \\
& $2006 / 07$ & 9.6 & 9.0 & 5.5 \\
$2007 / 08$ & 6.1 & 6.1 & 5.0 \\
$2008 / 09$ & -6.0 & -4.2 & 0.4 \\
$2009 / 10$ & 0.4 & 1.4 & 2.6 \\
$2010 / 11$ & 1.7 & 2.5 & 3.6 \\
$2011 / 12$ & 1.1 & 2.1 & 3.8 \\
$2012 / 13$ & 4.2 & 4.6 & 3.7 \\
$2013 / 14^{\mathrm{R}}$ & 4.0 & 4.5 & 4.0 \\
$2014 / 15^{\mathrm{P}}$ & 2.4 & 3.2 & 4.2 \\
\hline
\end{tabular}

Note: $\mathrm{R}=$ revised, $\mathrm{P}=$ provisional.

Source: Authors' calculations based on the following data:

(i) for 1957-96: 50 years of Pakistan, vol. 1 (1947-1997)

(http://www.pbs.gov.pk/sites/default/files/50_years_statistics/vol1/3.pdf);

(ii) for 1997-14: Pakistan Economic Survey for various years. 
Table A2: Total and NFNO imports as a percentage of GDP

\begin{tabular}{|c|c|c|}
\hline Year & $\begin{array}{c}\text { Total imports as percent of } \\
\text { GDP }\end{array}$ & $\begin{array}{c}\text { NFNO imports as percent of } \\
\text { GDP }\end{array}$ \\
\hline 1980 & 19.1 & 11.8 \\
\hline 1981 & 16.5 & 10.1 \\
\hline 1982 & 18.2 & 10.8 \\
\hline 1983 & 17.2 & 10.3 \\
\hline 1984 & 18.9 & 11.4 \\
\hline 1985 & 18.5 & 10.9 \\
\hline 1986 & 16.1 & 11.3 \\
\hline 1987 & 15.2 & 10.8 \\
\hline 1988 & 16.5 & 12.0 \\
\hline 1989 & 18.7 & 12.4 \\
\hline 1990 & 18.0 & 11.4 \\
\hline 1991 & 18.3 & 13.1 \\
\hline 1992 & 21.2 & 15.0 \\
\hline 1993 & 19.2 & 13.6 \\
\hline 1995 & 18.5 & 12.7 \\
\hline 1996 & 19.5 & 13.1 \\
\hline 1997 & 18.7 & 12.0 \\
\hline 1998 & 14.8 & 9.9 \\
\hline 1999 & 16.2 & 10.7 \\
\hline 2000 & 13.6 & 7.8 \\
\hline 2001 & 13.4 & 8.4 \\
\hline 2002 & 14.0 & 9.2 \\
\hline 2003 & 13.5 & 9.3 \\
\hline 2004 & 15.9 & 11.3 \\
\hline 2005 & 19.5 & 14.0 \\
\hline 2006 & 19.3 & 13.0 \\
\hline 2007 & 18.6 & 12.8 \\
\hline 2008 & 20.1 & 11.5 \\
\hline 2009 & 16.7 & 10.8 \\
\hline 2010 & 17.2 & 10.5 \\
\hline 2011 & 18.6 & 10.9 \\
\hline 2012 & 17.5 & 10.0 \\
\hline 2013 & 16.8 & 10.0 \\
\hline
\end{tabular}

Source: Authors' calculations based on data from the United Nations Commodity Trade Statistics database (accessed 10 July 2015). 
Table A3: Pakistan's imports from China (as reported by Pakistan and adjusted for underreporting)

US\$ million

\begin{tabular}{lccc}
\hline Year & $\begin{array}{c}\text { Total imports from } \\
\text { China as reported by } \\
\text { Pakistan }\end{array}$ & $\begin{array}{c}\text { Exports to Pakistan as } \\
\text { reported by China }\end{array}$ & $\begin{array}{c}\text { Difference between } \\
\text { reports }\end{array}$ \\
\hline 1980 & 168 & NA & NA \\
1981 & 180 & NA & NA \\
1982 & 148 & NA & NA \\
1983 & 147 & NA & NA \\
1984 & 145 & 256.3 & 111.8 \\
1985 & 144 & 175.5 & 31.4 \\
1986 & 163 & 208.2 & 45.0 \\
1987 & 232 & 271.3 & 39.2 \\
1988 & 249 & 281.9 & 32.6 \\
1989 & 321 & 329.4 & 8.5 \\
1990 & 337 & 344.5 & 7.9 \\
1991 & 358 & 432.3 & 73.9 \\
1992 & 421 & 551.4 & 130.6 \\
1993 & 437 & 751.9 & 315.3 \\
1995 & 515 & 788.6 & 273.3 \\
1996 & 574 & 623.0 & 48.7 \\
1997 & 585 & 689.2 & 104.4 \\
1998 & 423 & 523.4 & 100.7 \\
1999 & 447 & 580.6 & 133.8 \\
2000 & 550 & 670.3 & 120.2 \\
2001 & 487 & 815.0 & 328.0 \\
2002 & 699 & $1,242.1$ & 543.6 \\
2003 & 959 & $1,855.0$ & 897.7 \\
2004 & 1,489 & $2,465.8$ & 977.0 \\
2005 & 2,349 & $3,427.7$ & $1,078.3$ \\
2006 & 2,915 & $4,239.4$ & $1,324.4$ \\
2007 & 4,164 & $5,831.3$ & $1,313.0$ \\
2008 & 4,738 & $6,051.1$ & $1,735.3$ \\
2009 & 3,780 & $5,515.1$ & $1,690.1$ \\
2010 & 5,248 & $6,937.8$ & $1,969.1$ \\
2011 & 6,471 & $8,439.7$ & $2,588.9$ \\
2012 & 6,688 & $9,276.5$ & 4393.3 \\
2013 & 6,626 & $11,019.6$ & \\
\hline
\end{tabular}

Source: Authors' calculations based on data from the United Nations Commodity Trade Statistics database (accessed 10 July 2015). 
Table A4: Structure of LSM, Pakistan (contribution of value added)

\begin{tabular}{|c|c|c|c|c|}
\hline \multirow{2}{*}{$\begin{array}{l}\text { Industry code } \\
(2005 / 06)\end{array}$} & \multicolumn{4}{|r|}{ Percent } \\
\hline & Industry & $1990 / 91$ & $2000 / 01$ & $2005 / 06$ \\
\hline & All industries & 100.0 & 100.0 & $\overline{100.0}$ \\
\hline 17 & Manufacture of textiles & 26.4 & 25.4 & 26.3 \\
\hline 1711 & Spinning of textiles & 15.1 & 13.7 & 9.8 \\
\hline \multirow[t]{2}{*}{1712} & Textile fabrics & 3.1 & 3.4 & 7.3 \\
\hline & Silk and art silk textiles & 4.1 & 3.0 & 4.1 \\
\hline 1713 & Finishing of textiles & 0.9 & 1.9 & 2.2 \\
\hline 15 & Food products and beverages & 15.5 & 15.9 & 15.3 \\
\hline 1542 & Sugar & 7.9 & 4.9 & 3.9 \\
\hline 1514 & Vegetable and animal oils and fats & 1.7 & 3.7 & 3.3 \\
\hline 1520 & Dairy products & 0.3 & 0.9 & 2.5 \\
\hline 24 & Chemicals and chemical products & 15.0 & 16.6 & 15.9 \\
\hline 2412 & Fertilizers and nitrogen compounds & 4.6 & 3.7 & 4.8 \\
\hline 2423 & Pharmaceuticals & 4.6 & 5.9 & 4.7 \\
\hline 26 & Other nonmetallic mineral products & 6.6 & 4.7 & 6.5 \\
\hline 2694 & Cement, lime and plaster & 6.4 & 4.5 & 5.1 \\
\hline 18 & Wearing apparel & 1.4 & 2.9 & 4.7 \\
\hline 23 & Petroleum & 3.0 & 4.8 & 4.7 \\
\hline 34 & Motor vehicles and trailers ${ }^{2}$ & 2.0 & 3.0 & 4.5 \\
\hline 27 & Basic metals & 5.6 & 4.8 & 4.0 \\
\hline 15142 & Cotton ginning 1 & 1.2 & 2.9 & 2.7 \\
\hline 21 & Paper and paper products & 1.6 & 1.5 & 2.5 \\
\hline 16 & Tobacco products & 6.4 & 4.9 & 2.2 \\
\hline 29 & Machinery and equipment NEC & 2.5 & 1.3 & 2.0 \\
\hline 31 & Electrical machinery and apparatus NEC & 4.1 & 3.6 & 1.9 \\
\hline 35 & Other transport equipment ${ }^{2}$ & 0.6 & 0.2 & 1.5 \\
\hline 3591 & Motorcycles & 0.2 & 0.1 & 1.0 \\
\hline 25 & Rubber and plastic products & 1.5 & 1.2 & 1.0 \\
\hline \multirow[t]{2}{*}{19} & Leather products & 1.1 & 1.5 & 1.0 \\
\hline & Others & 5.7 & 4.8 & 3.3 \\
\hline
\end{tabular}

Note: In order to maintain consistency in industry codes across the series of years, the following industries in 2005/06 have been adjusted as follows:

1. Cotton ginning until $2000 / 01$ was given as a separate industry head. In 2005/06, this was included in the food products and beverages industry. Here, it is shown separately with its value deducted from the total for the food products and beverages industry.

2. Until 2000/01, motor vehicles, trailers and other transport equipment were reported under the combined heading of "transport equipment." Here, the two industries are shown separately as reported in 2005/06.

Source: Authors' calculations based on data from the Census of Manufacturing Industries for various years. 
Table A5: Structure of LSM, Sindh (contribution of value added)

\begin{tabular}{|c|c|c|c|c|}
\hline \multirow{2}{*}{$\begin{array}{l}\text { Industry code } \\
(2005 / 06)\end{array}$} & \multicolumn{4}{|r|}{ Percent } \\
\hline & Industry & $1990 / 91$ & $2000 / 01$ & $2005 / 06$ \\
\hline & All industries & 100.0 & 100.0 & 100.0 \\
\hline 17 & Manufacture of textiles & 20.7 & 17.4 & 21.0 \\
\hline 1711 & Spinning of textiles & 9.9 & 6.8 & 9.8 \\
\hline \multirow[t]{2}{*}{1712} & Textile fabrics & 4.0 & 4.3 & 5.3 \\
\hline & Silk and art silk textiles & 2.5 & 1.6 & 0.8 \\
\hline 1713 & Finishing of textiles & 0.9 & 1.6 & 2.1 \\
\hline 15 & Food products and beverages & 16.3 & 11.5 & 10.9 \\
\hline 1542 & Sugar & 9.0 & 4.6 & 4.3 \\
\hline 1514 & Vegetable and animal oils and fats & 2.0 & 1.8 & 1.6 \\
\hline 1520 & Dairy products & 0.01 & NA & 0.01 \\
\hline 24 & Chemicals and chemical products & 17.0 & 19.3 & 20.3 \\
\hline 2412 & Fertilizers and nitrogen compounds & 2.3 & 2.2 & 3.5 \\
\hline 2423 & Pharmaceuticals & 7.1 & 9.4 & 8.3 \\
\hline 26 & Other nonmetallic mineral products & 5.2 & 1.9 & 4.9 \\
\hline 2694 & Cement, lime and plaster & 4.9 & 1.7 & 3.9 \\
\hline 18 & Wearing apparel & 2.4 & 3.9 & 3.2 \\
\hline 23 & Petroleum & 4.6 & 9.9 & 9.3 \\
\hline 34 & Motor vehicles and trailers ${ }^{2}$ & 3.8 & 5.8 & 7.9 \\
\hline 27 & Basic metals & 10.0 & 9.1 & 6.3 \\
\hline 15142 & Cotton ginning 1 & 0.6 & 5.0 & 3.3 \\
\hline 21 & Paper and paper products & 0.3 & 0.4 & 0.3 \\
\hline 16 & Tobacco products & 2.4 & 3.7 & 1.2 \\
\hline 29 & Machinery and equipment NEC & 1.2 & 0.6 & 1.7 \\
\hline 31 & $\begin{array}{l}\text { Electrical machinery and apparatus } \\
\text { NEC }\end{array}$ & 4.9 & 4.6 & 2.4 \\
\hline 35 & Other transport equipment ${ }^{2}$ & 0.6 & 0.2 & 3.3 \\
\hline 3591 & Motorcycles & NA & NA & 2.1 \\
\hline 25 & Rubber and plastic products & 2.0 & 1.4 & 1.3 \\
\hline \multirow{2}{*}{19} & Leather products & 1.5 & 2.0 & 0.5 \\
\hline & Others & 6.6 & 3.3 & 2.4 \\
\hline
\end{tabular}

Note: In order to maintain consistency in industry codes across the series of years, the following industries in 2005/06 have been adjusted as follows:

1. Cotton ginning until $2000 / 01$ was given as a separate industry head. In 2005/06, this was included in the food products and beverages industry. Here, it is shown separately with its value deducted from the total for the food products and beverages industry.

2. Until 2000/01, motor vehicles, trailers and other transport equipment were reported under the combined heading of "transport equipment." Here, the two industries are shown separately as reported in 2005/06.

Source: Authors' calculations based on data from the Census of Manufacturing Industries for various years. 
Table A6: Structure of LSM, Punjab (contribution of value added)

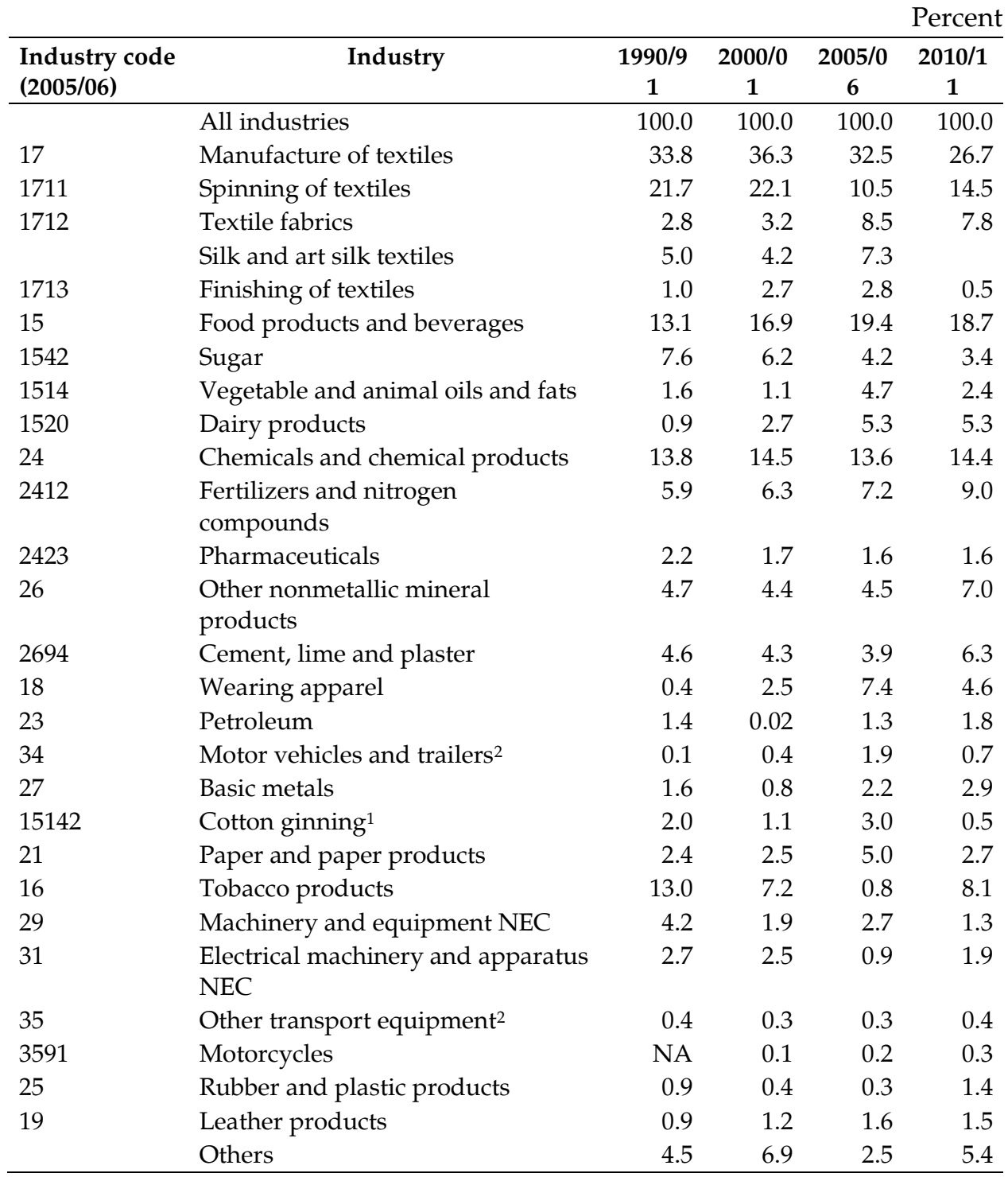

Note: In order to maintain consistency in industry codes across the series of years, the following industries in 2005/06 have been adjusted as follows:

1. Cotton ginning until 2000/01 was given as a separate industry head. In 2005/06, this was included in the food products and beverages industry. Here, it is shown separately with its value deducted from the total for the food products and beverages industry.

2. Until 2000/01, motor vehicles, trailers and other transport equipment were reported under the combined heading of "transport equipment." Here, the two industries are shown separately as reported in 2005/06.

Source: Authors' calculations based on data from the Census of Manufacturing Industries for various years. 
Table A7: Industrial structure by sophistication scores, Pakistan

\begin{tabular}{|c|c|c|c|c|c|c|}
\hline & \multirow[b]{2}{*}{ CMI code/description } & \multirow[b]{2}{*}{$\begin{array}{c}\text { Sophistication } \\
\text { score }\end{array}$} & \multicolumn{4}{|c|}{ Value added share of total (\%) } \\
\hline & & & $1990 / 91$ & $1995 / 96$ & $2000 / 01$ & $2005 / 06$ \\
\hline 292 & Special purpose machinery & 83.24 & 2.0 & 1.8 & 1.5 & 1.3 \\
\hline 343 & $\begin{array}{l}\text { Parts and accessories for motor } \\
\text { vehicles }\end{array}$ & 82.69 & - & - & - & 0.8 \\
\hline \multirow[t]{2}{*}{291} & General purpose machinery & 82.49 & 0.0 & 0.0 & 0.0 & 0.3 \\
\hline & Total sophistication level 1 & & 2.1 & 1.9 & 1.5 & 2.4 \\
\hline 242 & Other chemical products & 81.46 & 9.3 & 9.9 & 5.7 & 10.2 \\
\hline 331 & Medical and measuring & 81.37 & 0.2 & 0.3 & 0.5 & 0.6 \\
\hline 210 & Paper and paper products & 79.86 & 1.9 & 1.8 & 1.7 & 2.8 \\
\hline 160 & Tobacco products & 79.82 & 7.5 & 7.1 & 5.7 & 2.5 \\
\hline \multirow[t]{2}{*}{341} & Motor vehicles & 79.62 & 2.4 & 3.2 & 3.5 & 4.2 \\
\hline & Total sophistication level 2 & & 21.4 & 22.3 & 17.1 & 20.2 \\
\hline 261 & Glass and glass products & 75.71 & 0.8 & 0.4 & 0.4 & 0.7 \\
\hline \multirow[t]{2}{*}{155} & Beverages & 70.65 & 1.7 & 1.8 & 2.5 & 1.2 \\
\hline & Total sophistication level 3 & & 2.5 & 2.2 & 2.9 & 1.9 \\
\hline 252 & Plastic products & 69.20 & 0.6 & 0.5 & 0.9 & 0.9 \\
\hline 359 & Transport equipment & 68.15 & 0.3 & 0.6 & 0.2 & 1.2 \\
\hline 241 & Basic chemicals & 67.06 & 8.6 & 8.7 & 10.1 & 7.7 \\
\hline 311 & $\begin{array}{l}\text { DC motors, generators and } \\
\text { transformers }\end{array}$ & 66.27 & 0.5 & 0.3 & 0.1 & 1.2 \\
\hline \multirow[t]{2}{*}{271} & Basic iron and steel & 64.71 & 6.6 & 4.8 & 5.5 & 4.1 \\
\hline & Total sophistication level 4 & & 16.6 & 15.0 & 16.8 & 15.0 \\
\hline 289 & Other fabricated metal products & 59.13 & 0.9 & 0.7 & 1.4 & 0.9 \\
\hline 369 & Manufacturing NEC & 54.88 & 0.6 & 1.0 & 1.4 & 0.6 \\
\hline 293 & Domestic appliances & 54.70 & 2.4 & 4.6 & 0.4 & 0.7 \\
\hline 232 & Refined petroleum products & 54.51 & 3.5 & 3.5 & 9.3 & 5.2 \\
\hline 202 & Products of wood & 51.07 & 0.3 & 0.3 & 0.1 & 0.6 \\
\hline \multirow[t]{2}{*}{173} & $\begin{array}{l}\text { Knitted and crocheted fabrics } \\
\text { and articles }\end{array}$ & 50.75 & 0.9 & 0.9 & 2.5 & 1.2 \\
\hline & Total sophistication level 5 & & 8.7 & 11.0 & 15.1 & 9.2 \\
\hline 171 & $\begin{array}{l}\text { Textile spinning, weaving and } \\
\text { finishing }\end{array}$ & 46.41 & 23.2 & 20.7 & 22.5 & 26.1 \\
\hline 154 & Other food products & 44.66 & 10.9 & 11.0 & 7.0 & 6.1 \\
\hline 191 & Tanning and dressing of leather & 43.37 & 1.3 & 0.9 & 1.7 & 0.5 \\
\hline 269 & Nonmetallic products & 41.27 & 8.2 & 8.4 & 5.7 & 6.6 \\
\hline 151 & $\begin{array}{l}\text { Meat, fruit, vegetables, oils and } \\
\text { fats }\end{array}$ & 40.99 & 2.4 & 3.1 & 4.6 & 4.1 \\
\hline 181 & $\begin{array}{l}\text { Wearing apparel, except fur } \\
\text { apparel }\end{array}$ & 33.18 & 1.6 & 1.6 & 3.4 & 5.3 \\
\hline 172 & Other textiles & 30.77 & 0.7 & 1.4 & 0.8 & 2.0 \\
\hline \multirow[t]{3}{*}{192} & Footwear & 29.90 & 0.5 & 0.6 & 0.7 & 0.5 \\
\hline & Total sophistication level 6 & & 48.8 & 47.6 & 46.6 & 51.2 \\
\hline & Percentage of LSM included & & 84.0 & 87.0 & 86.0 & 90.0 \\
\hline
\end{tabular}

Source: Authors' calculations based on data from the Census of Manufacturing Industries for various years. Sophistication scores obtained from Lall, Weiss, and Zhang (2005). 
Table A8: Industrial structure by sophistication scores, Sindh

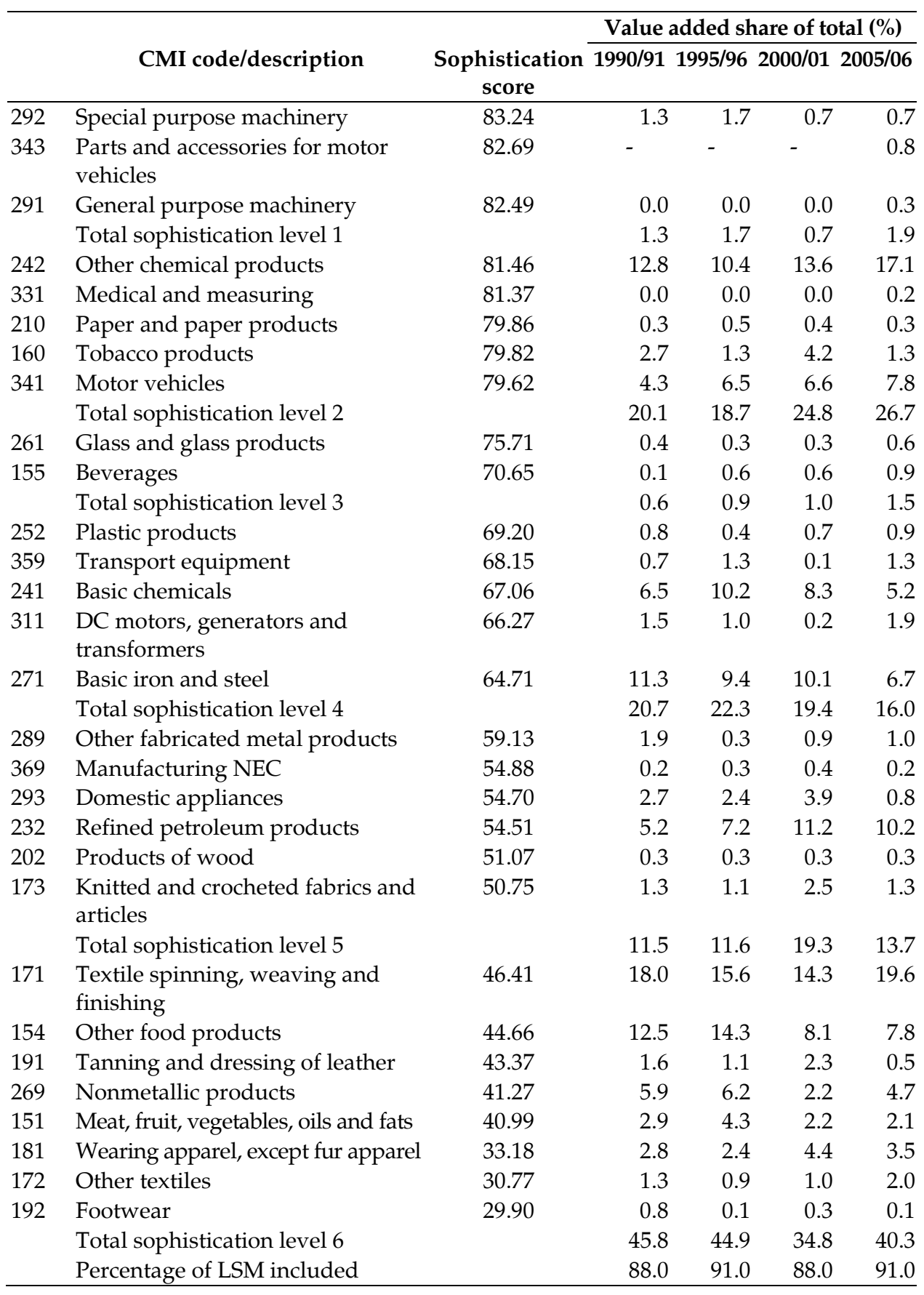

Source: Authors' calculations based on data from the Census of Manufacturing Industries for various years. Sophistication scores obtained from Lall, Weiss, and Zhang (2005). 
Table A9: Industrial structure by sophistication scores, Punjab

\begin{tabular}{|c|c|c|c|c|c|c|c|}
\hline \multirow[b]{3}{*}{292} & \multirow{3}{*}{$\begin{array}{c}\text { CMI code/description } \\
\text { Special purpose machinery }\end{array}$} & \multirow{3}{*}{$\begin{array}{c}\begin{array}{c}\text { Sophistication } \\
\text { score }\end{array} \\
83.24\end{array}$} & \multicolumn{5}{|c|}{ Value added share of total (\%) } \\
\hline & & & \multicolumn{5}{|c|}{ 1990/91 1995/96 2000/01 2005/06 2010/11 } \\
\hline & & & 4.9 & 1.7 & 2.2 & 2.0 & $\overline{1.1}$ \\
\hline 343 & $\begin{array}{l}\text { Parts and accessories for } \\
\text { motor vehicles }\end{array}$ & 82.69 & - & - & - & 0.3 & 0.6 \\
\hline \multirow[t]{2}{*}{291} & General purpose machinery & 82.49 & 0.0 & 0.0 & 0.0 & 0.3 & 0.4 \\
\hline & Total sophistication level 1 & & 4.9 & 1.8 & 2.2 & 2.6 & 2.1 \\
\hline 242 & Other chemical products & 81.46 & 6.1 & 8.9 & 5.0 & 4.5 & 3.3 \\
\hline 331 & Medical and measuring & 81.37 & & & & 1.1 & 1.9 \\
\hline 210 & Paper and paper products & 79.86 & 2.8 & 3.2 & 2.9 & 5.7 & 3.1 \\
\hline 160 & Tobacco products & 79.82 & 15.1 & 10.7 & 8.2 & 0.9 & 9.2 \\
\hline \multirow[t]{2}{*}{341} & Motor vehicles & 79.62 & 0.1 & 0.4 & 0.5 & 1.9 & 0.1 \\
\hline & Total sophistication level 2 & & 24.0 & 23.3 & 16.5 & 14.1 & 17.6 \\
\hline 261 & Glass and glass products & 75.71 & 0.8 & 0.4 & 0.3 & 0.3 & 0.5 \\
\hline \multirow[t]{2}{*}{155} & Beverages & 70.65 & 0.7 & 3.1 & 3.9 & 1.2 & 3.7 \\
\hline & Total sophistication level 3 & & 1.5 & 3.5 & 4.2 & 1.5 & 4.2 \\
\hline 252 & Plastic products & 69.20 & 0.1 & 0.4 & 0.4 & 0.3 & 0.6 \\
\hline 359 & Transport equipment & 68.15 & 0.5 & 0.5 & 0.3 & 0.4 & 0.4 \\
\hline 241 & Basic chemicals & 67.06 & 9.9 & 11.0 & 11.4 & 10.9 & 12.4 \\
\hline 311 & $\begin{array}{l}\text { DC motors, generators and } \\
\text { transformers }\end{array}$ & 66.27 & 0.6 & 0.6 & 0.2 & 0.9 & 0.2 \\
\hline \multirow[t]{2}{*}{271} & Basic iron and steel & 64.71 & 1.9 & 1.0 & 0.8 & 2.3 & 3.2 \\
\hline & Total sophistication level 4 & & 13.0 & 13.5 & 13.2 & 14.7 & 16.8 \\
\hline 289 & $\begin{array}{l}\text { Other fabricated metal } \\
\text { products }\end{array}$ & 59.13 & 0.3 & 0.2 & 1.6 & 0.4 & 0.4 \\
\hline 369 & Manufacturing NEC & 54.88 & 1.2 & 1.3 & 3.0 & 1.1 & 2.4 \\
\hline 293 & Domestic appliances & 54.70 & 1.9 & 2.4 & 2.5 & 0.7 & 1.9 \\
\hline 232 & Refined petroleum products & 54.51 & 1.6 & 0.4 & 0.0 & 1.4 & 2.0 \\
\hline 202 & Products of wood & 51.07 & 0.2 & 0.2 & 0.1 & 0.3 & 0.1 \\
\hline \multirow[t]{2}{*}{173} & $\begin{array}{l}\text { Knitted and crocheted } \\
\text { fabrics and articles }\end{array}$ & 50.75 & 0.6 & 1.0 & 2.9 & 1.3 & 0.2 \\
\hline & Total sophistication level 5 & & 5.9 & 5.6 & 10.0 & 5.2 & 7.0 \\
\hline 171 & $\begin{array}{l}\text { Textile spinning, weaving } \\
\text { and finishing }\end{array}$ & 46.41 & 30.3 & 27.5 & 32.1 & 33.1 & 26.0 \\
\hline 154 & Other food products & 44.66 & 9.3 & 11.1 & 8.0 & 5.7 & 4.6 \\
\hline 191 & $\begin{array}{l}\text { Tanning and dressing of } \\
\text { leather }\end{array}$ & 43.37 & 1.0 & 1.1 & 1.4 & 0.7 & 1.0 \\
\hline 269 & Nonmetallic products & 41.27 & 5.8 & 7.6 & 5.3 & 4.8 & 7.4 \\
\hline 151 & $\begin{array}{l}\text { Meat, fruit, vegetables, oils } \\
\text { and fats }\end{array}$ & 40.99 & 2.1 & 2.4 & 1.8 & 5.5 & 2.9 \\
\hline 181 & $\begin{array}{l}\text { Wearing apparel, except fur } \\
\text { apparel }\end{array}$ & 33.18 & 0.5 & 1.2 & 2.9 & 8.4 & 5.3 \\
\hline 172 & Other textiles & 30.77 & 0.6 & 0.5 & 1.1 & 2.5 & 4.2 \\
\hline \multirow[t]{3}{*}{192} & Footwear & 29.90 & 1.2 & 1.1 & 1.4 & 1.1 & 0.7 \\
\hline & Total sophistication level 6 & & 50.7 & 52.4 & 53.9 & 61.8 & 52.2 \\
\hline & Percentage of LSM included & & 86.0 & 89.0 & 88.0 & 88.0 & 88.0 \\
\hline
\end{tabular}

Source: Authors' calculations based on data from the Census of Manufacturing Industries for various years. Sophistication scores obtained from Lall, Weiss, and Zhang (2005). 


\section{Methodology for calculating the sophistication index industrial structure}

The Census of Manufacturing Industries (CMI) classification is based on the Pakistan Standard Industrial Classification (PSIC). This had to be matched to the Standard International Trade Classification (SITC), which is what Lall et al. (2005) use to assign sophistication scores to different industries.

In order to obtain sophistication scores against the 3-digit CMI level, only those industries were considered that accounted for 0.5 percent or more of the total industries' value added in the CMI.19 Industries for which a sophistication score was not available in the sophistication classification prepared by Lall et al. (2005) were omitted. For the selected set $^{20}$ of industries for each 3-digit CMI, all products at the 4-digit or 5-digit CMI level were identified that contributed at least 5 percent of the value added of that industry at the 3-digit CMI level. As an example, below we describe the steps involved in calculating the weighted average sophistication score for one industry at the CMI 3-digit level, i.e., other chemical products (PSIC 242). The 4-digit or 5-digit CMI level description was matched ${ }^{21}$ to the 3 -digit SITC level.

\begin{tabular}{llccl}
\hline $\begin{array}{l}\text { CMI } \\
\text { (PSIC) }\end{array}$ & \multicolumn{1}{c}{ Description } & $\begin{array}{c}\text { \% Share } \\
\text { value added }\end{array}$ & SITC & \multicolumn{1}{c}{ Description } \\
\hline 242 & $\begin{array}{l}\text { Other chemical } \\
\text { products } \\
\text { Paints, varnishes, } \\
\text { printing ink } \\
\text { Pharmaceuticals }\end{array}$ & 5.43 & 533 & $\begin{array}{l}\text { Pigments paints, varnishes } \\
\text { and related materials } \\
\text { Medicinal and }\end{array}$ \\
2423 & 52.03 & 541 & $\begin{array}{l}\text { Mharmaceutical products } \\
\text { phap, cleansing and }\end{array}$ \\
2424 & Soaps and detergents & 15.13 & 554 & $\begin{array}{l}\text { Soaph } \\
\text { polishing preparations } \\
\text { Miscellaneous chemical } \\
\text { products }\end{array}$ \\
\hline
\end{tabular}

${ }^{19}$ We consider those 4-digit and 5-digit level codes in the CMI that contribute most to the 3-digit level in the CMI in terms of the weights calculated, adding up the weights of the industries considered to make up the denominator. The individual weights of the same 4-digit or 5-digit industries are used as the numerator.

${ }^{20}$ Despite these omissions, the value-added share of industries included in the structure ranges from 84 to 91 percent of the total CMI value added for that year.

${ }^{21} \mathrm{We}$ assign weights to each of the 4-digit and 5-digit level CMI codes under 3-digit level in the CMI. The weights are calculated as: $\left[\frac{\text { Value added of } 4 \text { or } 5 \text { digit CMI codes under the } 3 \text { digit code }}{3 \text { digit CMI code for the same industry }}\right]$. 
The percentage value-added shares of the matched 4-digit or 5digit CMI level in each industry at the 3-digit level in the CMI were taken as weights. These weights were used to calculate the weighted proportion of each 3-digit SITC level as shown below:

\begin{tabular}{lcc}
\hline SITC code & $\begin{array}{c}\text { Percent share valued } \\
\text { added (weights) }\end{array}$ & Weighted proportion \\
\hline 533 & 5.430 & 0.055 \\
541 & 52.03 & 0.531 \\
554 & 15.13 & 0.154 \\
598 & 26.46 & 0.260 \\
& 98.06 & 1.000 \\
\hline
\end{tabular}

Note: Formula used for code 533 is: [ $\left.\frac{\% \text { Share valued added of } 533}{\text { Total sum of weights }}\right]$

We multiplied the weighted proportion of each 3-digit SITC level by its sophistication score given by Lall et al. (2005), and added the products to obtain this weighted sophistication score against each industry at the 3-digit CMI level as shown in the table below:

\begin{tabular}{lccc}
\hline Industrial code & $\begin{array}{c}\text { Lall et al. (2005) } \\
\text { sophistication score 2000 }\end{array}$ & $\begin{array}{c}\text { Weighted } \\
\text { proportion }\end{array}$ & $\begin{array}{c}\text { Contribution to CMI } \\
\text { sophistication score }\end{array}$ \\
\hline 533 (SITC) & 79.61 & 0.055 & 4.41 \\
541 (SITC) & 83.91 & 0.531 & 44.52 \\
554 (SITC) & 69.44 & 0.154 & 10.72 \\
598 (SITC) & 83.99 & 0.260 & 21.81 \\
242 (CMI/PSI) & & 1.000 & 81.46 \\
\hline
\end{tabular}

Note: Formula used for code 533 is: [Sophistication score 2000 for 533 * weighted proportion 533]

Formula for weighted average score is: $\sum$ [Sophistication score 2000 * weighted proportion]

After quantifying sophistication scores for all 3-digit CMI codes and using the same methodology, we allocated these scores among six groups of different sophistication levels ranging from 1 to 6 according to Lall et al. (2005), where 1 represents the most sophisticated industries and 6 represents the least so. 